\title{
Earnings Management and Initial Public Offerings (IPOs) at Tehran Stock Exchange (TSE)
}

\author{
Bagher Shamszadeh \\ Assistant Professor of Accounting Dept., Bu Ali Sina University, Hamadan, Iran \\ Corresponding Author, Email: shamszadeh@basu.ac.ir \\ Arezo Bakhtiari \\ MSc of Accounting, Health Organization, Hamadan, Iran \\ Email: bakhtiyariarezoo@yahoo.com
}

\section{Doi:10.5901/mjss.2015.v6n6s6p92}

\begin{abstract}
This paper attempted to examine the earnings management in the initial public offerings of corporate shares at Tehran Stock Exchange (TSE). Using a sample 47 companies listed on Tehran Stock Exchange during 2000 to 2009, this research analyzes the model for discretionary current accruals. The results showed managers manipulated the corporate earnings through the discretionary current accruals three years before admission to the Stock Exchange manage. Additionally, the results revealed that managers tended to manipulate the earnings during the year prior to the public offerings though the discretionary current accruals, even though there was no evidence suggesting that managers manipulated the earnings at the IPO year.
\end{abstract}

Keywords: initial public offerings, earnings management, discretionary current accruals

\section{Introduction}

One of the key economic and financial issues in the world involves the public offerings of shares and transfer of private to public ownership. This is often concerned by companies since there is a great deal of profit, tax cuts and access to lowcost financial resources. As a result, many companies in different countries venture into initial public offerings of their shares. During the public offerings, the corporate managers usually hold private information about the upcoming cash flow, investment opportunities and management skills. In contrast, investors are uncertain about the prospects of companies that for the first time offer their shares to the public. Due to such information asymmetry, the IPO companies are requested to publish a notebook containing the audited financial statements. The financial statements can help investors determine the price they want to pay per corporate share. For example, a 1999 study by Kim and Ritte in the United States showed that there is a significantly positive relationship between figures appearing in financial statements and stock price. However, these financial statements reflect the value of assets and liabilities, as well as identification of income and expenses, which in turn represent the optional choices under GAAP (Nile, Pursiow and Schiffer, 1995). The data in financial statements serve to motivate the managers throughout the pricing process with accounting freedom to manage their earnings at IPO.

\subsection{Problem statement}

It is more risky to purchase the shares of new entrants to the stock market as compared to other companies; because they lack trading experience and relevant historical data (Firth, 1998). This leads to information asymmetry between managers and investors.

Many people invest their savings in securities at IPOs, where some investors rely on the company's reported profits et al. ignore the performance indicators. Since the financial statements of listed companies are prepared based on GAAP and accruals, the managers may decide on the time for identification and calculation of income and expenses, thus taking advantage of the investor's negligence about the temporary increase of profits through accruals. This might in turn lead to earnings management. This study intended to clarify whether earnings management occurs during IPOs at the TSE, and how managers can apply the discretionary accruals before and after the IPOs. 


\section{Literature Review}

Haley and Vahlen (1999) defined earnings management as "judgment in financial reporting and organizing the transactions for modifying the financial statements aimed at misleading some of the shareholders about the key economic performances of the company or influencing the result of contracts relying on numbers reported by accountants." The key element of financial reporting includes cash flow from operations in addition to accruals that determines the accounting profits. The judgment on accruals can influence the specific earnings by replacing the identification of events and transactions where the respective cash flow takes place. When the accrual accounts increase during the current period, the managers of IPO companies can borrow in the incomes from another period aimed at manipulation without violating the accounting rules. An important feature of accrual-based earnings management is that the total accruals become based zero, because the total earnings during the corporate lifetime is supposed to be the total cash flow. As a result, any amount higher than normal accruals within a given period should be a value lower than the normal accruals during the other periods, so that managers of companies with poor prospects cannot overestimate the earnings from remote periods without the manipulations discovered. Therefore, it is expected that if the IPO companies exercise the accounting freedom, they will alter the financial statements relating to the public offering of shares. After all, the financial statements will leave the greatest impact on the decisions made by the contributors to the capital market (Peter Roosenboom et al., 2003). However, the decision to increase short-term profits will be at the expense of long-term periods. That is because managers are forced to reverse the accrual accounts over the next periods so as to be able to sustain the inflated profits for an unlimited time. This will most likely work inversely for the companies with poor performance, because the companies with good performance are more likely to improve the cash flow without the need for overreporting. As a result, it is expected to guide the discovery of earnings management of outside investors through gradual understanding of the future earnings quality, thus assess the value of IPO companies inclining downwards, where they are engaged with accrual-based earnings management (Peter Roosenboom et al., 2003).

\subsection{Accruals}

Jones (1991) defined accruals as the difference between earnings and cash flow from operations, dividing it into two categories which have been recognized by all the literature concerning the accruals.

A) Non-discretionary accruals

Items created in the business model of companies and their operating environment without the involvement of a business unit management but rather created during the corporate business activities (1991).

B) Discretionary current accruals (DCA)

Items created due to selection of accounting practices, discretionary allocations, management decisions and judgments and estimations. In other words, the amount and type of these items can vary from company to another, since they are affected by the selected procedures and policies adopted by the company. The more a manager is free to modify such items, there will more likely be impact the earnings (Francis, 2005, Dechow et al., 1995). Therefore, they can be used as an indicator to detect earnings management.

The accruals are separated into discretionary and non-discretionary through different methods, such as Hailie's model (1999), De Angelo's model (1994), Jones model (1991), modified Jones Model (2004) and Industry Model (1995) (Dechow et al., 1995). In this study, the earnings management at the companies listed in Tehran Stock Exchange was examined through the modified version of Jones model (1991). The Jones model (1991) assumes that the accruals are subject to the real business of companies and thecriteria of each corporate activity is specified through the sales of the company. It is assumed in the modified Jones's Model that earnings management is manipulated by changes in the accounts receivable. It also assumes that all the changes in credit sales originate from earnings management (Dechow et al., 1995).

\section{Literature Review}

There are several studies demonstrating the application of earnings management in relation to the securities offered in the United States. Freedlan (1994) showed that IPO companies use the earning-boosting accruals in most of the financial statements in the prospectus initial offering of securities. Magnan and Pierre Kurmanbek (1997) reported that the IPO Canadian companies took well-measured and calculated steps to replace move data to forecast the reported earnings for discretionary accruals during the initial offering in the first year as a public stock company. Theo et al (1998) found that 
companies that report positive accruals in the first year will experience poor performance over the stock price in the next three years. Roosenboom et al. (2003) studied 64 Dutch companies with initial offerings during in 1984-19949, concluding that average accruals in the year prior to the IPO and the IPO year was higher than that in the next years. Pastor et al. (2005), examined a total of 65 Spanish IPO companies during 1987-2002, concluding that the average accruals in the IPO year were higher. Ducharm et al. (2004) concluded that there is earnings management in the IPO year. Armstrong et al., 2009) conducted a scrutiny into the US companies during 1987-2005, concluding that discretionary accruals was negative in the year before the initial offering and positive in the initial offering. In contrast Aharon et al. (1993) obtained no evidence of manipulation in the period prior to the initial offerings.

Noroush et al. (2005) evaluated the earnings management at companies listed in Tehran Stock Exchange during 1996 to 2003. Their research findings showed that large companies in Iran attempted earnings management, where the incentive grows as debts go up. The findings also showed that managers of large companies used the accruals for lowering the corporate tax. Larger companies tend to carry out more earnings management. Mashayekhi et al. (2005) evaluated the role of discretionary accruals in earnings management at companies listed in Tehran Stock Exchange through the modified Jones model, founding out that companies applied earnings management. In fact, the managers of these companies attempted to increase earnings through discretionary accruals when there was reduction in the cash flow from operations, which reflects the poor performance of a business unit. In a study on the impact of earnings management on investment decisions at companies listed in Tehran Stock Exchange through the Acle Index, Mohammadi (2006) concluded that companies applied earnings management leading to presentation of unrealistic financial information. In a study titled "earnings management through activities effective in operating cash flow at companies listed in Tehran Stock Exchange", Dorosti (2006) showed that companies reporting lower annual earnings tend to manipulate real activities. These companies avoid reporting losses usually through price discounts (which temporarily increases sales) and higher production (which reduces the cost of goods) and curtail discretionary costs (which are dependent on the personal opinion of the management). It seems the companies also manipulate the actual operational activities so as to avoid reporting of low earnings. Mashayekhi and Safari (2006) evaluated the relationship between cash flow from operations of manufacturing companies listed on Tehran Stock Exchange and the behavior of discretionary accruals during 2000 to 2003. The results of this study suggested that when cash from operations is weak, companies tend to adopt strategies to increase profits. As for companies with good operational activity (on the basis of cash from operations), however, there is reduction in accruals. Nevertheless, they observed that a considerable number of companies with strong activity also tend to adopt the increased earnings policy, while some companies with excellent operating activities tend to have lower earnings policies.

In a research into earnings management at the time of initial public offerings at 30 IPO companies during 1999 to 2006, Ebrahimi Kordlar et al. (2006) showed that managers manipulated the corporate profits in the years before the initial delivery and the initial public offering year. In addition, the effect of earnings management on the long-term performance of IPO companies was examined to find out there is a relationship between discretionary current accruals over the first year and the long-term performance of share prices over the next three years.

\section{Research Hypotheses}

\subsection{Research questions}

Since the admission terms of companies at the Tehran Stock Exchange involves their profitability in three consecutive financial periods, where certain companies differed in terms of admission year and IPO years, several questions arise:

1. Does earnings management at the Tehran Stock Exchange occur during IPOs like other developed stock exchange markets?

2. Does earnings management at the Tehran Stock Exchange occur during admission?

\subsection{Research hypotheses}

The research questions were answered through two hypotheses as follow: 


\subsection{Hypotheses of group one}

First hypothesis: Iranian companies manage the earnings through the discretionary current accruals in the year prior to IPOs.

Second hypothesis: Iranian companies manage the earnings through the discretionary current accruals in the IPO years.

Third hypothesis: Iranian companies manage the earnings through the discretionary current accruals in the year after IPOs.

\subsection{Hypotheses of group two}

First hypothesis: Iranian companies manage the earnings through the discretionary current accruals two years prior to admission at the TSE.

Second hypothesis: Iranian companies manage the earnings through the discretionary current accruals one year prior to admission at the TSE.

Third hypothesis: Iranian companies manage the earnings through the discretionary current accruals in the admission year at the TSE.

Fourth hypothesis: Iranian companies manage the earnings through the discretionary current accruals one year after admission at the TSE.

\section{Methodology}

This study focused on the initial public offering as the independent variable for the first group and on the admission to stock exchange for the second group of hypotheses. Moreover, it was the dependent variable intended for both groups of earnings management, where was measured through discretionary current accruals.

In this study, earnings management was measured through working capital accruals or current accruals.

$\mathrm{CA}_{\mathrm{j}, \mathrm{t}}=\Delta \mathrm{Ca}_{\mathrm{j}, \mathrm{t}}-\Delta \mathrm{Cl}_{\mathrm{j}, \mathrm{t}}-\Delta \mathrm{CaSh}_{\mathrm{j}, \mathrm{t}}+\Delta \mathrm{STDEBT}_{\mathrm{j}, \mathrm{t}}$

$\mathrm{CA}_{\mathrm{j}, \mathrm{t}}=$ total corporate current accruals

$\Delta \mathrm{Ca}, \mathrm{t}=$ Changes in current assets

$\Delta \mathrm{Cl}_{\mathrm{j}, \mathrm{t}}=$ Changes in current liabilities

$\triangle$ STDEBT $_{\mathrm{j}, \mathrm{t}}=$ Changes in the current portion of long-term liabilities

$\Delta$ Cash $_{\mathrm{j}, \mathrm{t}}=$ Changes in cash

After calculating $C A_{j, t}$, the Jones model was used to estimate the factors $\beta_{0}, \beta_{1}$.

1) $\frac{C A_{j, t}}{T A_{j, t-1}}=\beta_{0}\left(\frac{1}{T A_{j, t-1}}\right)+\beta_{1}\left(\frac{\Delta R E V_{j, t}}{T A_{j, t-1}}\right)+\varepsilon_{j, t}$

$\mathrm{CA}_{\mathrm{j}, \mathrm{t}}=$ total corporate current accruals

$\mathrm{TA}_{\mathrm{j}, \mathrm{t}-1}=$ total assets in year $\mathrm{t}-1$

$\triangle R E V_{j, t}=$ change in sales revenue versus sales in year t minus the sales in year $t-1$

$\beta_{0}, \beta_{1}=$ Company-specific factors

Then, the modified Jones model and the estimated parameters, and the discretionary current accruals were calculated using the following equations:

$\frac{D C A_{i, t}}{T A_{i, t-1}}=\frac{C A_{i, t}}{T A_{i, t-1}}-\hat{\beta}_{0}\left(\frac{1}{T A_{i, t-1}}\right)-\hat{\beta}_{1}\left(\frac{\Delta R E V_{i, t}-\Delta A R_{i, t}}{T A_{i, t-1}}\right)$

$D C A_{j, t}=$ discretionary current accruals

$\mathrm{CA}_{\mathrm{j}, \mathrm{t}}=$ total current accruals

$\triangle \mathrm{REE} \mathrm{V}_{\mathrm{j}, \mathrm{t}}=$ changes in sales revenue versus sales in year $\mathrm{t}$ minus the sales in year $\mathrm{t}-1$

$T A_{j, t-1}=$ total assets in year $t-1$

$\Delta \mathrm{AR}, \mathrm{t}=$ change in accounts receivable and the accounts receivable in year t minus accounts receivable in year $\mathrm{t}-1$

$\beta_{0}, \beta_{1}=$ Company-specific factors

\section{Statistical Population and Sample}

The population comprised all the companies listed on Tehran Stock Exchange during 2003-2006. Then, the following conditions and limitations were applied so as to select the qualified samples. 
Table 1. Admission from 2003 to 2006 at TSE

\begin{tabular}{|c|c|c|c|c|c|c|}
\hline \multicolumn{2}{|c|}{ Variable } & Sample size & Min. & Max. & Mean & Standard deviation \\
\hline \multirow{6}{*}{ CA / TA } & -2 & 47 & -0.28 & 0.51 & 0.0826 & 0.17040 \\
\cline { 2 - 7 } & -1 & 47 & -3.7 & 0.49 & -0.0313 & 0.58969 \\
\cline { 2 - 7 } & 0 & 47 & -0.63 & 0.70 & 0.0338 & 0.25354 \\
\cline { 2 - 7 } & 1 & 47 & -0.39 & 1.20 & 0.0502 & 0.26311 \\
\cline { 2 - 7 } & 2 & 47 & -0.63 & 0.66 & 0.0509 & 0.23086 \\
\cline { 2 - 7 } & 3 & 47 & -0.12 & 0.00 & 0.1315 & 0.29681 \\
\hline \multirow{6}{*}{ / TA } & -2 & 47 & 0.00 & 0.00 & 0.00 & 0.00001 \\
\cline { 2 - 7 } & -1 & 47 & 0.00 & 0.00 & 0.00 & 0.00001 \\
\cline { 2 - 7 } & 0 & 47 & 0.00 & 0.00 & 0.00 & 0.00001 \\
\cline { 2 - 7 } & 1 & 47 & 0.00 & 0.00 & 0.00 & 0.00001 \\
\cline { 2 - 7 } & 2 & 47 & 0.00 & 0.00 & 0.00 & 0.00001 \\
\cline { 2 - 7 } & 3 & 47 & 0.00 & 0.00 & 0.00 & 0.00001 \\
\hline \multirow{6}{*}{ REV / TA } & -2 & 47 & -0.20 & 1.52 & 0.3057 & 0.29806 \\
\cline { 2 - 7 } & -1 & 47 & 0.4387 & -0.02 & 0.4387 & 0.64005 \\
\cline { 2 - 7 } & 0 & 47 & 3.55 & -0.18 & 0.4336 & 0.66371 \\
\cline { 2 - 6 } & 1 & 47 & -0.38 & 0.88 & 0.2030 & 0.25298 \\
\cline { 2 - 6 } & 2 & 47 & -0.27 & 0.68 & 0.1321 & 0.20605 \\
\cline { 2 - 6 } & 3 & 47 & -0.34 & 1.09 & 0.1587 & 0.24503 \\
\hline
\end{tabular}

1. Fiscal year ending in March without changes in fiscal years.

2. Available required data.

3. Investment and financial credit institutions were excluded, because those companies rarely manipulated earnings through discretionary accruals. They mostly attempted the sale of investments and other techniques for earnings management.

Therefore, the population comprised a total of 47 companies listed in Tehran Stock Exchange that met the above criteria. The time span of the study was limited to years from 2000 to 2009 , where the corresponding information were used to estimate the Jones model factors (Event period), while the years from 2003 to 2006 to examine the details of the modified Jones model (Estimation period).

\section{Statistical Analysis}

Table 2. Descriptive statistics of data

\begin{tabular}{|c|c|c|c|c|c|}
\hline Variable & Sample size & Min. & Max. & Mean & Standard deviation \\
\hline$(-2)$ & 47 & -0.27 & 0.59 & 0.0685 & 0.1667 \\
\hline$(-2)$ & 47 & -2.86 & 0.61 & 0.0436 & 0.48606 \\
\hline$(0)$ & 47 & -0.56 & 1.12 & 0.1045 & 0.28639 \\
\hline$(1)$ & 47 & -0.34 & 1.06 & 0.0768 & 0.22139 \\
\hline$(2)$ & 47 & -0.61 & 0.72 & -0.62 & 0.22373 \\
\hline$(3)$ & 47 & -0.11 & 1.29 & 0.1551 & 0.22527 \\
\hline
\end{tabular}

Table 3. Descriptive statistics of DCA/TA

\begin{tabular}{cccc}
\hline Model & F & Sig. & Durbin-Watson \\
\hline Regression & 14.747 & 0.000 & 2.355 \\
\hline
\end{tabular}

Table 4. ANOVA Table of Jones' Model

\begin{tabular}{|c|c|c|c|c|c|}
\hline Model & \multicolumn{2}{|c|}{ Coefficients } & T & Sig. & Effect of variable \\
\hline \multirow{2}{*}{1} & $\beta_{0}$ & 735.981 & 0.623 & 0.533 & Rejected \\
\cline { 2 - 6 } & $\beta_{1}$ & -0.225 & -5.431 & 0.000 & Proved \\
\hline
\end{tabular}


Considering the F-value and significance level of over 0.05 , the regression equation was proved. The Durbin-Watson statistic suggested there was no correlation between the components of regression model error (the values of this coefficient should be somewhere between 1 and 2.5).

Normality hypothesis:

If the regression hypotheses are true, the distribution of both regular and standardized residuals will be nearly normal. For that purpose, the Kolmogorov-Smirnov test was employed with the following results:

Table 6. Kolmogorov-Smirnov test for normality of the distribution of the residual variables

\begin{tabular}{|l|c|c|c|c|c|c|}
\hline \multirow{2}{*}{} & \multicolumn{3}{|c|}{ Kolomogrov-smirnov(a) } & \multicolumn{3}{c|}{ Shapiro-Wilk } \\
\cline { 2 - 7 } & statistic & df & Sig. & statistic & df & Sig. \\
\hline Unstandardized residual & 0.180 & 280 & 0.224 & 0.978 & 224 & 0.874 \\
\hline
\end{tabular}

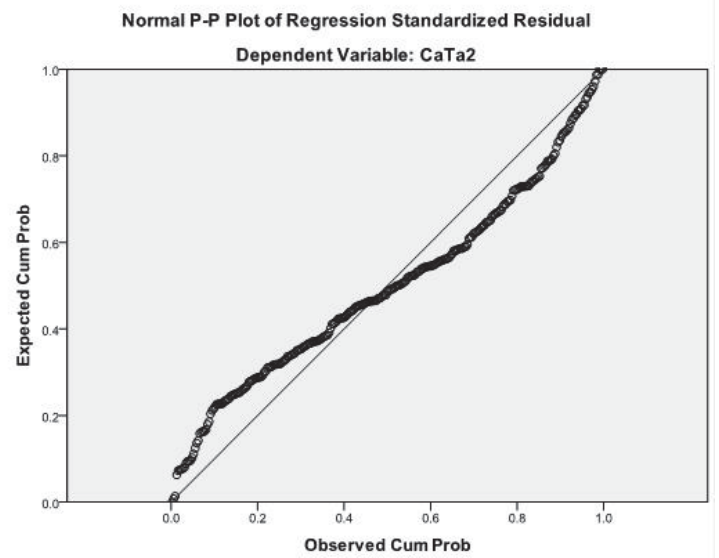

Figure 1. Graph for the standardized regression residuals

In this paper, earnings management was explored through the modified Jones model (Dechow et al. 1995). The hypotheses were tested through the student t-test. Since the criterion for earnings management was $0.15 \%$, it should be within the confidence interval. The hypotheses were either proved or rejected based on two statistics. Firstly, the significance level of the test (sig) must be less than 0.05. Secondly, the confidence interval must meet the earnings management criterion. If two criteria in the hypotheses testing are true, then the hypothesis shall be proved. In research by Magnan, Kremier and Theo et al. (1997), and Theo et al (1998), it was revealed that values of discretionary current accruals more than $1.5 \%$ of the total amount of assets represented earnings management. The data were analyzed through the SPSS.

\subsection{Hypotheses testing of the first group:}

First hypothesis: Do the Iranian companies manage the earnings through the discretionary current accruals in the year prior to IPOs?

Second hypothesis: Do the Iranian companies manage the earnings through the discretionary current accruals in the IPO years?

Third hypothesis: Do the Iranian companies manage the earnings through the discretionary current accruals in the year after IPOs? 
Table 7. T-test for the hypothesis of the group one

\begin{tabular}{|c|c|c|c|c|c|c|}
\hline \multicolumn{9}{|c|}{ Test Value $=0$} & \multicolumn{2}{c|}{ Confidence interval } \\
\hline Variable & T statistic & df & Sig. (2-tailed) & Mean difference & Lower limit & Upper limit \\
\hline DCA/TA(-1) & 4.094 & 47 & 0.000 & 0.15502 & 0.0788 & 0.2313 \\
\hline DCA/TA(0) & 2.020 & 47 & 0.049 & 0.06854 & 0.0002 & 0.1369 \\
\hline DCA/TA(+1) & 2.018 & 45 & 0.050 & 0.07204 & 0.0002 & 0.1439 \\
\hline
\end{tabular}

As can be seen in the results of Table 7, since the significance level is over 0.05 there is a significant relationship. Moreover, the confidence interval suggests that Iranian companies manage their earnings in the year prior to IPO, but not at the IPO year and the next years.

\subsection{Hypotheses testing of the second group:}

First hypothesis: Do the Iranian companies manage the earnings through the discretionary current accruals two years prior to admission at the TSE?

Second hypothesis: Do the Iranian companies manage the earnings through the discretionary current accruals one year prior to admission at the TSE?

Third hypothesis: Do the Iranian companies manage the earnings through the discretionary current accruals in the admission year at the TSE?

Fourth hypothesis: Do the Iranian companies manage the earnings through the discretionary current accruals one year after admission at the TSE?

Table 8. T-test for the hypothesis of the group two

\begin{tabular}{|c|c|c|c|c|c|c|}
\hline \multicolumn{7}{|c|}{ Test Value $=0$} \\
\hline Variable & T statistic & df & Sig. (2-tailed) & Mean difference & \multicolumn{2}{c|}{ Confidence interval limit } \\
\hline DCA/TA(-2) & 5.147 & 46 & 0.000 & 0.12445 & 0.0758 & 0.1731 \\
\hline DCA/TA(-1) & 3.615 & 46 & 0.042 & 0.04360 & -0.0991 & 0.1863 \\
\hline DCA/TA(0) & 2.501 & 46 & 0.016 & 0.10446 & 0.0204 & 0.1885 \\
\hline DCA/Ta (1) & 2.161 & 46 & 0.036 & 0.07677 & 0.0053 & 0.1483 \\
\hline
\end{tabular}

As can be seen in the results of Table 8, since the significance level is over 0.05 there is a relationship. Moreover, the confidence interval suggests that Iranian companies managed their earnings through discretionary current accruals two years prior to admission, but not in a year after admission.

\section{Summary and Conclusions}

According to the first hypothesis, Iranian companies manage the earnings through the discretionary current accruals in the year prior to IPOs. The results of hypothesis testing showed that the companies managed their earnings in the year prior to initial public offering. In this respect, the majority of relevant studies around the world proved the hypothesis of earnings management one year prior to IPO. For instance, Friedlan (1994), Theo et al.(1998) Roosenboom et al. (2003) and Ali Ebrahimi Kordlar, and Elham Hasani, Azar Dariani D (2006).

According to the second hypothesis, Iranian companies manage the earnings through the discretionary current accruals in the IPO years. The results of hypothesis testing demonstrated that companies never managed the earnings during the IPO year. The results of IPO in the previous year were similar to those obtained by relevant studies.

According to the third hypothesis, Iranian companies manage the earnings through the discretionary current accruals in the year after IPOs. The results of hypothesis testing demonstrated that companies never managed the earnings after the IPO year. The results were therefore different from those obtained by the relevant studies.

Furthermore, Since the admission terms of companies at the Tehran Stock Exchange involves their profitability in three consecutive financial periods, where certain companies differed in terms of admission year and IPO years, this paper also concentrated on earnings management over the three consecutive financial periods leading up to admission. It was revealed that Iranian companies managed their earnings in all the three financial periods ending in admission, even 
though such earnings management did not occur over the next year. Evidently, since it is banned to sell deducted shares to be and research shows that there are no cheap IPOs in the Tehran Stock Exchange (Zeinab Haghbin, 2008), it is more important for companies than initial offerings, which is why they tend to manage the earnings over the three years prior to admission to the TSE.

\subsection{Recommendations based on the results}

According to the results, there are several recommendations made below:

- The authorities formulating the standards and regulations ought to set standards and regulations for IPO reporting so as to minimize the possibility of manipulating the items leading to earnings management.

- The admission criteria at the Tehran Stock Exchange cover the profitability of companies over the last three years. It is better to employ other indicators that can barely been manipulated by the management to so to assess the company's performance and ultimately whether a company should be admitted or rejected at the TSE.

\subsection{Suggestions for future research}

Regarding the vital requirements in Iran and the fact that little research has so far been carried out about the newly arrived companies, there is a potential realm for further study on the following areas:

1. Effect of boom and bust cycles on the earnings management of new entrants to the Tehran Stock Exchange

2. Effective factors such as the type of auditors report, type of ownership, cost of capital and type of industry on the earnings management of new entrants

3. Evaluation of the efficiency of information market and its impact on corporate earnings management of new entrants to the Tehran Stock Exchange

4. Examining the role of auditing and regulatory mechanisms and its impact on earnings management of newly arrived companies at Tehran Stock Exchange

5. Further evaluating the results of the current research through comparing the results with those obtained by various models (Dechow and Eslen, Haley, De Angelo).

6. Considering the fact that this study examined the earnings management through manipulation of discretionary current accruals, the management earnings can be alternatively evaluated based on the timing of identification events.

7. Examining the classification of corporate components in financial statements for the years before and after admission to the TSE.

\section{Research Limitations}

In this study, few samples were selected for examining the relationship between the Initial Public Offerings and earnings management. However, the use of more samples could have overshadowed the results.

\section{References}

Kordlar Ebrahimi, Ali. Elham Hsani, Azar Dariani. (2006) "Earnings management at IPOs at companies listed in Tehran Stock Exchange" Review of accounting and auditing Journal,Tehran, No. 45: 3-23.

Haghbin, Zeinab. (2008). "Different types of anomalies related to the initial public offerings at Tehran Stock Exchange." Master's thesis in business administration, University of Al-Zahra (SA) p. 9-24

Dorosti, AA. (2006). "Phenomenon of earnings management through activities affecting the operating cash flows of companies listed in Tehran Stock Exchange." Master's thesis in accounting, international University of Imam Khomeini, School of Humanities Page 15-45.

Riahi Balkuyee. Ahma, (2002). "Accounting Theories" Ali Parsian, Tehran. Cultural Research Publications.

Mohammadi, Jamal. (2006) "The effect of earnings management on the investment decisions made by companies listed in the Tehran Stock Exchange." Master Thesis in Accounting, Islamic Azad University, Neishabour Branch. Page 11-54.

Mashayekhi, B. Safari, Maryam, Summer.(2006) "cash flow from operations and earnings management at companies listed in Tehran Stock Exchange" accounting and auditing reviews; 13 (44): 35-54.

Mashayekhi, Bita Mehrani, Sasan Mehrani, Kaveh, Karami, Gholamreza Winter (2005) "The role of discretionary accruals in earnings management at Tehran Stock Exchange," Journal of Accounting and Audit - Issue 42 - pp 61-74. 
Noravesh, Iraj. Sepasi, S. and Nikbakht, MR.(2005) "Earnings management at companies listed in Tehran Stock Exchange" Journal of Humanities and Social Sciences, University of Shiraz (43)

Malcolm Smith. (2011) "Methodology in Accounting", Ali Parsayyan, Tehran, Tarmeh Publications.

Aharony, J., C.J. Lin and M.P. Loeb. (1993). "Initial public offerings, accounting choices and earnings management." Contemporary Accounting Research 10(1):pp.61-81.

Armstrong, C.S., Foster, G. and Taylor, D.J., (2009). Earnings Management around Initial Public Offerings: Working paper, available at SSRN: http://ssrn.com/abstract=1147328

Copeland, R.M. (1968) Income smoothing. Journal of accounting Research, Empiri-cal Research in Accounting, Selected Studies 6(Supplement): 101-116.

Dechow, P., R. Sloan and A. Sweeney. (1995). "Detecting earnings management." The Accounting Review 70(2):pp. 193-225.

Ducharme, L.L., Malatesta P.H. and Sefcik, S.E., (2004). Earnings management, stock issues and shareholder issues. Journal of Financial Economics 71, pp. 27-49.

Firth, M. Branson C.H.Kwok, and C.K Liau-Tan (1995), «Accuracy of profit forecasts contained in the IPO Prospectuses», Accounting and Business Review, 2(1): 55-83.

Francis J, R LaFond, P Olsson, K Skipper, (2005), The market pricing of Accruals Quality, Journal of Accounting and Economics" 39: 295-327.

Friedlan, J.M. (1994). "Accounting choices of issuers of initial public offerings." Contemporary Accounting Research 11(1):pp. 1-31.

Healy, P. M., and J. M. wahlen, (1999). A review of the earnings management literature and its implications for standard setting. Accounting Horizons 13 (December): 365-383.

Jones, J. (1991) "Earnings management during import relief investigations. Journal of Accounting Research 29(2): pp. $193-228$.

Kim, M., \& Ritter, J. R. (1999, September). Valuing IPOs. Journal of Financial Economics, 53(3), 409-437.

Magnan, M. and D. Cormier. (1997). "The impact of foreward-looking financial data in IPOs on the quality of financial reporting." Journal of financial statement analysis 3(2): pp.6-17.

Neill, J. D., Pourciau, S. G., \& Schaefer, T. F. (1995, September). Accounting method choice and IPO valuation. Accounting Horizons, $9(3), 68-80$.

Pastor-Llorca, M.J. and Poveda Fuentes, F., (2005). Earnings Management and the Long run Performance of Spanish Initial Public Offerings. Published in: Initial Public Offerings: An International Perspective, Greg N. Gregoriou (Ed.), Elsevier ButterworthHeinemann, chapter 7, pp. 81-112.

Ronen, J., \& S. Sadan. (1981). Smoothing income numbers. Reading, Mass: Addison-Wesley. Sheid, J. C., \& Walton, P. 1995. European accounting guide. (2nd ed.). London: H B \& Jovanovich.

Roosenboom, P., T. V.D. Goot and G. Mertens (2003). "Earnings management and initial public offerings: Evidence from the Netherlands." The International of Accounting 38, pp. 243-266.

Schipper, K. (1989). Commentary on earnings management. Accounting Horizons 3(4): 91-102.

Scott, W. (1997). Financial Accounting Theory. Prentice -Hall.

Teoh, S.H., I. Welch and T.J. Wong. (1998). "Earnings management and the long run market performance of initial public offerings." The Journal Of Finance (6): pp.1935-1974. 